\title{
Biokonversi limbah ampas tahu dan limbah sayur dengan menggunakan agen larva Black Soldier Fly (Hermetia illucent)
}

\section{Bioconversion of tofu waste and vegetable waste using Black Soldier Fly (Hermetia illucent) larvae agent}

\author{
Listya Purnamasari ${ }^{1 *}$, Wildan Muhlison², dan Irwanto Sucipto \\ ${ }^{1}$ Program Studi Peternakan, Fakultas Pertanian, Universitas Jember, Jl. Kalimantan \\ No. 37, Jember 68121 \\ ${ }^{2}$ Program Studi Agroteknologi, Fakultas Pertanian, Universitas Jember, Jl. Kalimantan \\ No. 37, Jember 68121 \\ *Email Koresponden: listyap.faperta@unej.ac.id
}

\begin{abstract}
Abstrak. Sejumlah sampah organik yang dihasilkan sebagian besar masih belum dikelola dengan baik sehingga dapat berdampak buruk terhadap lingkungan. Teknologi paling mudah yang dapat digunakan untuk memanfaatkan sampah organik adalah pengomposan. Salah satu agen serangga yang saat ini popular dan dapat digunakan sebagai dekomposer limbah organik adalah larva Black Soldier Fly (Hermetia Illucent). Penelitian ini bertujuan untuk menganalisis mutu hasil biokonversi limbah organik sayur dan ampas tahu dengan menggunakan larva BSF. Parameter yang diuji yaitu derajat keasaman $(\mathrm{pH})$, kadar air $(\mathrm{KA})$, nitrogen $(\mathrm{N})$, fosfor $(\mathrm{P})$, rasio $\mathrm{C} / \mathrm{N}$, dan kalium $(\mathrm{K})$. Hasil pengujian menunjukkan bahwa limbah organik ampas tahu dan limbah sayur yang telah dibiokonversi dengan menggunakan larva BSF selama 15 hari menghasilkan nilai $\mathrm{N}, \mathrm{P}, \mathrm{K}, \mathrm{C} / \mathrm{N}, \mathrm{pH}$, dan $\mathrm{KA}$ yang sesuai dengan persyaratan SNI 19-7030-2004 tentang Spesifikasi kompos dari sampah organik domestik. Sehingga dapat disimpulkan bahwa larva BSF mampu mendekomposisi limbah organik dengan cepat dan menghasilkan pupuk organik yang bermanfaat bagi tanah, tanaman dan lingkungan.
\end{abstract}

Kata kunci: biokonversi, black soldier fly, larva, maggot

\begin{abstract}
Most of the organic waste has not been managed properly so that it can harm the environment. The easiest technology that can be used to utilize organic waste is composting. One of the insect agents that are currently popular and can be used as a decomposer of organic waste is Black Soldier Fly (Hermetia Illucent) larvae. This study aims to analyze the quality of the results of bioconversion of organic vegetable waste and tofu dregs using BSF larvae. The parameters tested were the degree of acidity $(\mathrm{pH})$, water content, nitrogen $(N)$, phosphorus $(P), C / N$ ratio, and potassium $(K)$. The test results showed that the organic waste tofu waste and vegetable waste that had been bioconverted using BSF larvae for 15 days produced $N, P, K, C / N, p H$, and $K A$ values following the requirements of SNI 19-7030-2004 concerning Specifications. compost from domestic organic waste. It can be concluded that BSF larvae can decompose organic waste quickly and produce organic fertilizers that are beneficial to soil, plants, and the environment.
\end{abstract}

Keywords: bioconversion, black soldier fly, larvae, maggot 
Purnamasari et al.

ANIMPRO: Conference of Applied Animal Science Proceeding Series

\section{PENDAHULUAN}

Jumlah penduduk di Indonesia yang setiap tahun meningkat berbanding lurus dengan peningkatan jumlah sampah yang dihasilkan. Menurut FAO (Food and Agriculture Organization) (2014), setiap tahun sepertiga dari jumlah makanan yang diproduksi terbuang dan menjadi sampah organik. Jumlah sampah organik yang dihasilkan di Indonesia mencapai $60 \%$ dari total jenis sampah yang dihasilkan. Sejumlah sampah organik yang dihasilkan sebagian besar masih belum dikelola dengan baik sehingga dapat berdampak buruk terhadap lingkungan. (Kaza et al. 2018). Limbah organik mengandung energi dan nutrisi yang berharga, dapat berkontribusi pada peningkatan emisi gas rumah kaca tahunan (GRK) (Dai et al., 2016). Kandungan Carbon, Nitrogen dan Phospor yang terlalu tinggi dalam sampah organik juga berdampak buruk pada lingkungan seperti eutrofikasi ekosistem air ((Diaz and Rosenberg 2008) pertumbuhan ganggang/alga yang tinggi, (Glibert, 2017), pengasaman ekosistem darat (tanah) yang menurunkan hasil panen (Huang et al., 2012) dan beresiko pada penyebaran bakteri pathogen yang berbahaya (Rehman et al., 2017).

Oleh karena itu, penting untuk menemukan cara yang efektif untuk mendaur ulang sampah organik ini. Teknologi paling mudah yang dapat digunakan untuk memanfaatkan sampah organik adalah pengomposan. Salah satu agen serangga yang saat ini popular dan dapat digunakan sebagai dekomposer limbah organik adalah larva Black Soldier Fly (Hermetia Illucent). Larva BSF mampu mengkonsumsi berbagai macam sumber daya organik mulai dari limbah makanan, produk sampingan agribisnis, kotoran hewan hingga produk berbasis daging (Schmitt \& de Vries, 2020). Budidaya lalat ini tergolong mudah, murah dan cepat serta memiliki potensi memproduksi pakan ternak kaya nutrien (Liu et al., 2019) bahan bakar (Rehman et al., 2017), pupuk organic (Song et al., 2020) mengurangi limbah nitrogen dan fosfor hingga $75 \%$ serta mampu menjadi agen biokonversi kotoran ternak ayam dan babi hingga menyusut 50\% (Abd El-Hack et al., 2020; Newton et al., 2005) dan menghasilkan produk turunan lainnya (Caligiani et al., 2018) secara bersamaan.

Salah satu sampah yang sangat melimpah dan belum termanfaatkan dengan baik adalah sampah sayur dan ampas tahu. Ampas tahu memiliki kandungan nutrien seperti protein $26,6 \%$, karbohidrat $42 \%$ dan mineral 55\% (Suhartini, 2009) sedangkan limbah sayur memikiki kandungan nutrien protein kasar sebesar $1-15 \%$ dan serat kasar $5-38 \%$ (Jalaluddin et al., 2018). Nutrien tersebut dapat dibiokonversi menjadi nutrien lain yang bisa bermanfaat bagi tanah, tumbuhan maupun hewan. Penelitian ini bertujuan untuk menganalisis mutu hasil biokonversi limbah organik sayur dan ampas tahu dengan menggunakan larva BSF.

\section{MATERI DAN METODE}

Bahan yang digunakan dalam penelitian ini yaitu limbah ampas tahu, limbah sayur, larva BSF umur 5 hari $(5 \mathrm{DOL})$. Alat yang digunakan yaitu $\mathrm{pH}$ meter, ayakan/saringan kain, timbangan digital, bak pemeliharaan maggot, oven, labu kjeldahl. Parameter yang diuji yaitu derajat keasaman $(\mathrm{pH})$, kadar air $(\mathrm{KA})$, nitrogen $(\mathrm{N})$, fosfor $(\mathrm{P})$, rasio $\mathrm{C} / \mathrm{N}$, dan kalium $(\mathrm{K})$ sesuai metode yang dilakukan (Purnamasari et al., 2020). Proses biokonversi larva BSF pada media ampas tahu dan limbah sayur berlangsung selama 15 hari. Sebanyak $5 \mathrm{~g}$ BSFL berumur 5 hari dikembangbiakkan pada media limbah sayur maupun ampas tahu sebanyak $15 \mathrm{~kg}$ selama 15 hari.

Media residu hasil pembiakan larva BSFL diambil setelah 15 hari sebagai sampel pengujian. Pengukuran kadar air dilakukan dengan pemanasan pada suhu $105^{\circ} \mathrm{C}$ selama 24 jam. Pengukuran kadar $\mathrm{N}$ dilakukan dengan mengambil $0,25 \mathrm{ml}$ larutan residu larva BSF dan memasukkannya ke dalam labu Kjeldahl, bersama dengan asam sulfat 2,5 $\mathrm{ml}$ dan katalis selenium $0,25 \mathrm{~g}$. Larutan dicerna sampai jernih, kemudian ditambahkan larutan penyimpanan dalam labu Erlenmeyer $125 \mathrm{ml}$ yang terdiri dari larutan $\mathrm{H}_{3} \mathrm{BO}_{3} 4 \%$ dan dua atau tiga tetes BCGMR (Brom Cresol Green dan Methyl Red), kemudian disuling. Proses distilasi dihentikan jika lebih banyak gelembung keluar dari solusi penyimpanan. Hasil destilasi dititrasi dengan $\mathrm{HCl} 0,01$ $\mathrm{N}$. Kadar fosfor $\left(\mathrm{P}_{2} \mathrm{O}_{5}\right)$ diukur dengan mencampurkan $2 \mathrm{ml}$ larutan residu larva BSF dengan $10 \mathrm{ml}$ 
Purnamasari et al.

ANIMPRO: Conference of Applied Animal Science Proceeding Series

$\mathrm{HCl} 25 \%$ dan disimpan selama \pm 24 jam. Selanjutnya, $2 \mathrm{ml}$ campuran larutan diambil dan ditambahkan dengan $18 \mathrm{ml}$ air suling. Larutan yang telah diencerkan, ditambahkan $0,5 \mathrm{ml} \mathrm{NH}_{4}$ molibdat dan 2-3 tetes $\mathrm{SnCl}_{2}$, kemudian diukur menggunakan spektrofotometer dengan panjang gelombang $693 \mathrm{~nm}$. Hasil pengukuran yang didapat dibandingkan dengan kurva standar. Kadar kalium (K) diukur dengan menambahkan $1 \mathrm{ml}$ larutan residu larva BSF dengan $25 \mathrm{ml} 25 \% \mathrm{HCl}$ untuk dekon-konstruksi. Campuran $65 \% \mathrm{HNO}_{3}$ dan $\mathrm{HClO}_{4}$ dengan perbandingan dari 2:1 dan kemudian dilakukan konstruksi ulang dengan menambahkan $10 \mathrm{ml} \mathrm{HCl} 37 \%$ sampai sampel berwarna putih. Hasil dari penghancuran diencerkan menjadi $250 \mathrm{ml}$; selanjutnya diambil sebanyak $5 \mathrm{ml}$ kemudian disalurkan dan diencerkan hingga $10 \mathrm{ml}$ dan diukur menggunakan AAS (atomic absorption spectrophotometer). Data hasil pengujian dari biokonversi limbah ampas tahu dan limbah sayur dengan agen BSF dilakukan analisis secara deskriptif dengan membandingkan dengan pupuk kompos berdasarkan SNI 19-7030-2004 (BSN, 2004).

\section{HASIL DAN PEMBAHASAN}

Aktivitas manusia di berbagai bidang termasuk sektor pertanian dan peternakan menghasilkan limbah organik dan anorganik. Limbah organik mencapai $60 \%$ dari total limbah yang dihasilkan. Limbah organik mengandung komponen yang masih dapat bermanfaat. Pentingnya pengelolaan limbah organik ini yaitu memperbaiki kualitas lingkungan serta menghasilkan produk baru yang lebih bermanfaat. Pengomposan dilakukan untuk mendekomposisi bahan organik dengan bantuan organisme lain seperti mikroorganisme (bakteri, jamur, kapang) maupun agen serangga. Serangga yang saat ini banyak dipelajari untuk biokonversi limbah organik adalah lalat Black Soldier Fly/BSF (Hermetia illucent). Lalat BSF memiliki bentuk tubuh seperti tawon dengan pola warna hitam dan putih di sekujur tubuhnya (Tomberlin \& Sheppard, 2002). Siklus hidup BSF (Gambar. 1) sama seperti lainnya Arthropoda holometabola. Lalat dewasa hidup selama kurang lebih dua minggu dan hanya membutuhkan air untuk bertahan hidup. Lalat dewasa hanya kawin sekali, dan lalat betina akan bertelur satu kali selama hidup mereka dan akan mati beberapa saat setelah bertelur. Telur akan menetas sekitar empat hari dan pertumbuhan larva berlangsung selama dua minggu untuk hidup (Tomberlin \& Sheppard, 2002). Pada fase larva inilah mereka membutuhkan makanan untuk tumbuh dan berkembang. Fase prepupa merupakan tahap larva sebelum menjadi kepompong dengan mengosongkan sistem pencernaannya dan mencari tempat yang kering dan terlindungi. Sebagai tempat untuk menjadi kepompong (Craig Sheppard et al., 1994). Fase pupa juga membutuhkan sekitar dua minggu untuk berkembang menjadi lalat dewasa.

Larva BSF mampu hidup di lingkungan yang cukup ekstrim, seperti di media/sampah yang banyak mengandung garam, alkohol, acid/asam dan amonia. Mereka juga dapat hidup di suasana yang hangat, dan jika udara lingkungan sekitar sangat dingin atau kekurangan makanan, maka larva BSF tidak mati tapi mereka menjadi fakum atau tidak aktif menunggu sampai cuaca menjadi hangat kembali atau makanan sudah tersedia kembali. Selain itu, mereka juga dapat hidup di air atau dalam suasana alkohol (Gold et al., 2018), produk sampingan agribisnis, kotoran hewan hingga berbasis daging produk (Bonelli et al., 2019) Karakteristik larva BSF yaitu mampu membiokonversi sampah organik, dapat hidup dalam toleransi $\mathrm{pH}$ yang cukup tinggi, tidak membawa gen penyakit, mempunyai kandungan protein yang cukup tinggi, masa hidup sebagai larva cukup lama ( \pm 2 minggu), dan mudah dibudidayakan(Suciati \& Faruq, 2017). Beberapa karakteristik dan kemampuan larva BSF tersebut menjadi potensi tinggi dalam menangani sampah organik dibandingkan dengan organisme lain.

Komposisi substrat atau media perkembangbiakan memiliki dampak besar pada perkembangan BSF, kelangsungan hidup, komposisi nutrisi, dan laju biokonversi substrat. Jenis substrat/media akan berpengaruh pada lama waktu perkembangbiakan yaitu antara dua minggu hingga beberapa bulan dan larva yang dihasilkan dapat memiliki kandungan protein mulai dari 10 hingga $40 \%$ dari berat badan (Oonincx et al., 2015). Selain media, ukuran partikel yang besar (yaitu, sayuran utuh atau produk daging) yang sulit untuk dicerna oleh BSF akan berpengaruh pada komposisi nutrisi dan laju biokonversinya (Isibika et al., 2019). 


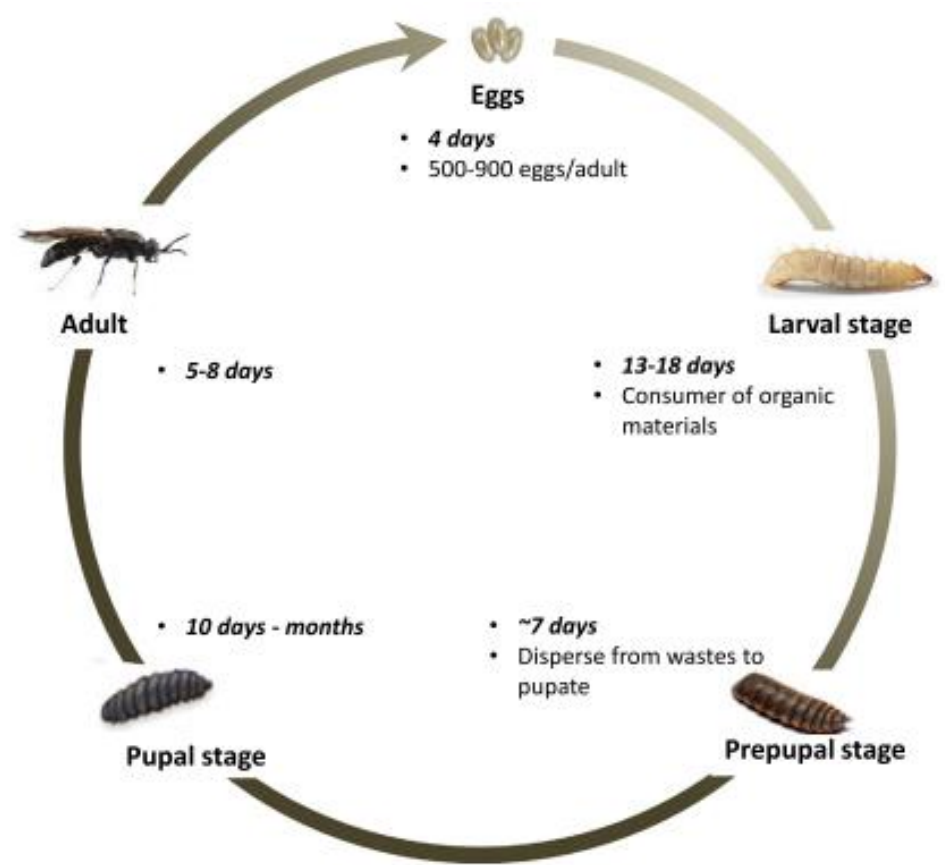

Gambar 1. Siklus hidup larva black soldier fly (BSF) (Surendra et al., 2020)

Salah satu hasil dari biokonversi sampah organik menggunakan larva BSF menghasilkan bahan stabil seperti kompos yang memiliki manfaat bagi lingkungan. Larva BSF mampu mereduksi limbah hingga 58\% dan menurunkan konsentrasi populasi nitrogen dalam limbah organic (Myers et al., 2008). Sebelum dilakukan biokonversi limbah ampas tahu dan limbah sayur yang akan digunakan diuji terlebih dahulu, hasil pengujian kandungan bahan tersaji pada Tabel 1. Kompos dapat digunakan sebagai sumber nutrisi bagi tanaman dan sebagai bahan penggembur tanah. Pada penelitian ini, hasil biokonversi yang diuji merupakan bahan yang telah diurai oleh larva BSF selama 15 hari. Mutu hasil biokonversi dibandingkan dengan standar yang terdapat dalam SNI 19-7030-2004 (Tabel 3.) tentang Spesifikasi Kompos dari Sampah Organik Domestik. Hasil pengujian disajikan pada Tabel 2.

Tabel 1. Kandungan media ampas tahu dan limbah sayur.

\begin{tabular}{lccccc}
\hline Jenis limbah & $\mathrm{pH}$ & Kadar Air (\%) & C-organik (\%) & Nitrogen (\%) & $\mathrm{C} / \mathrm{N}$ \\
\hline Ampas tahu & 6 & 87,6 & 66,8 & 1,8 & 37,11 \\
Limbah sayur & 6 & 92,2 & 81,3 & 2,1 & 38,93 \\
\hline
\end{tabular}

Kadar air merupakan salah satu faktor yang berperan penting dalam keberhasilan proses pengomposan. Kadar air yang terlalu tinggi dapat menyebabkan terjadinya kondisi anaerobic sedangkan apabila terlalu rendah dapat menyebabkan kondisi terlalu kering. Tingginya kandungan air pada media yang akan digunakan dalam proses biokonversi maka dilakukan penyaringan/dewatering selama 24 jam sebelum perlakuan penelitian. Proses ini dilakukan untuk mendapatkan kondisi optimum larva mampu bertahan hidup dan melakukan proses dekomposisi yaitu pada kadar air 55\% (Purnamasari et al., 2019) dan kondisi optimum pengomposan (Mazza et al., 2020). Selain dewatering, pencacahan limbah sayur juga dilakukan untuk menyeragamkan bentuk media dengan ampas tahu serta memperkecil ukuran limbah sehingga mempermudah larva BSF mencerna (Schmitt \& de Vries, 2020). 
Purnamasari et al.

ANIMPRO: Conference of Applied Animal Science Proceeding Series

Tabel 2. Hasil dekompisisi larva BSF pada media ampas tahu dan limbah sayur.

\begin{tabular}{lccccccc}
\hline Jenis limbah & $\mathrm{pH}$ & Kadar Air (\%) & C-organik (\%) & Nitrogen (\%) & $\mathrm{P}_{2} \mathrm{O}_{5}(\%)$ & $\mathrm{K}_{2} \mathrm{O}(\%)$ & $\mathrm{C} / \mathrm{N}$ \\
\hline Ampas tahu & 6,86 & 39,57 & 12,41 & 0,42 & 0,63 & 1,11 & 29,54 \\
Limbah sayur & 7,05 & 42,15 & 28,5 & 2,39 & 0,43 & 2,11 & 13,17 \\
\hline
\end{tabular}

Hasil biokonversi larva BSF pada media ampas tahu dan limbah sayur menunjukkan kandungan $\mathrm{N}$ dan $\mathrm{K}$ limbah sayur lebih tinggi dibandingkan dengan limbah ampas tahu. Hal ini disebabkan karena kandungan $\mathrm{C}$ organic limbah sayur lebih tinggi sehingga bahan organic yang dapat diurai dan dikonversi menjadi nitrogen dan kalium lebih tinggi yaitu 2,39\% pada limbah sayur dan $0,42 \%$ pada ampas tahu serta kalium $2,11 \%$ pada limbah sayur dan $1,11 \%$ pada ampas tahu. Proses dekomposisi bahan organik melibatkan bakteri nitrogen yang akan menghasilkan nilai nitrogen yang tinggi (Rezafie, 2019). Penurunan kadar C-organik pada media setelah dibiokonversi oleh larva BSF menunjukkan bahwa terjadi proses dekomposisi C-Organik dengan lepasnya ikatan karbon yang kompleks menjadi ikatan yang sederhana akibat penggunaan karbon tersbut oleh larva untuk mendapatkan energi dalam siklus hidupnya melalui proses respirasi dan biosintesis dengan pelepasan gas $\mathrm{CO}_{2}$ (Anwar, 2009).

Tabel 3. Kandungan kompos berdasar SNI 19-7030-2004.

\begin{tabular}{|c|c|c|c|c|c|c|}
\hline $\mathrm{pH}$ & Kadar Air (\%) & C-organik (\%) & Nitrogen (\%) & $\mathrm{P}_{2} \mathrm{O}_{5}(\%)$ & $\mathrm{K}_{2} \mathrm{O}(\%)$ & $\mathrm{C} / \mathrm{N}$ \\
\hline Min 6.8 & $\operatorname{Max}$ & Min 9,8 & Min 0,4 & $\operatorname{Min} 0,1$ & Min 0,2 & Min 10 \\
\hline Max 7.49 & 50 & Max 32\& & Max - & Max - & Max - & $\operatorname{Max} 20$ \\
\hline
\end{tabular}

Sumber: SNI (2004)

Kandungan Nitrogen pada hasil biokonversi limbah sayur oleh BSF lebih tinggi yaitu 2,39\% dibandingkan nilai nitrogen limbah sebelum dikonversi yaitu 2,1\%. Hal ini disebabkan karena adanya aktivitas biokimia larva yang menghasilkan sekresi nitrat dan adanya volatisasi nitrogen dalam bentuk ammonia (Sarpong et al., 2019). Kandungan phosphor yang terbentuk dalam proses biokonversi disebabkan adanya proses mineralisasi oleh mikroorganisme dengan mengubah C organic menjadi senyawa phosphor (Widarti et al., 2015). Hasil penelitian juga menunjukkan bahwa kandungan $\mathrm{N}, \mathrm{P}, \mathrm{K}, \mathrm{C}$-Organik dan kadar air serta kematangan $\mathrm{C} / \mathrm{N}$ rasio hasil biokonversi larva BSF pada media ampas tahu dan limbah sayur telah memenuhi persyaratan umum kompos berdasarkan SNI 19-7030-2004.

\section{KESIMPULAN}

Hasil pengujian menunjukkan bahwa limbah organik ampas tahu dan limbah sayur yang telah dibiokonversi dengan menggunakan larva BSF selama 15 hari menghasilkan nilai $\mathrm{N}, \mathrm{P}$, $\mathrm{K}, \mathrm{C} / \mathrm{N}$, pH, dan KA yang sesuai dengan persyaratan SNI 19-7030-2004 tentang Spesifikasi kompos dari sampah organik domestik. Sehingga dapat disimpulkan bahwa larva BSF mampu mendekomposisi limbah organik dengan cepat dan menghasilkan pupuk organik yang bermanfaat bagi tanah, tanaman dan lingkungan.

\section{DAFTAR PUSTAKA}

Abd El-Hack, M. E., Shafi, M. E., Alghamdi, W. Y., Abdelnour, S. A., Shehata, A. M., Noreldin, A. E., Ashour, E. A., Swelum, A. A., Al-sagan, A. A., Alkhateeb, M., Taha, A. E., Abdel-moneim, A. M. E., Tufarelli, V., \& Ragni, M. (2020). Black soldier fly (Hermetia illucens) meal as a promising feed ingredient for poultry: A comprehensive review. Agriculture (Switzerland), 10(8), 1-31. https://doi.org/10.3390/agriculture10080339

Anwar, E. K. (2009). Efektivitas Cacing Tanah Pheretima hupiensis, Edrellus sp. dan Lumbricus sp. dalam Proses Dekomposisi Bahan Organik Ea. 14(2), 149-158.

Bonelli, M., Bruno, D., Caccia, S., Sgambetterra, G., Cappellozza, S., Jucker, C., Tettamanti, G., \& Casartelli, M. (2019). Structural and functional characterization of hermetia illucens larval midgut. Frontiers in Physiology, 10, 1-18. https://doi.org/10.3389/fphys.2019.00204

BSN. (2004). Spesifikasi Kompos dari Sampah Organik Domestik SNI 19-7030-2004. 
Purnamasari et al.

ANIMPRO: Conference of Applied Animal Science Proceeding Series

Caligiani, A., Marseglia, A., Leni, G., Baldassarre, S., Maistrello, L., Dossena, A., \& Sforza, S. (2018). Composition of black soldier fly prepupae and systematic approaches for extraction and fractionation of proteins, lipids and chitin. Food Research International, 105, 812-820. https://doi.org/10.1016/j.foodres.2017.12.012

Craig Sheppard, D., Larry Newton, G., Thompson, S. A., \& Savage, S. (1994). A value added manure management system using the black soldier fly. Bioresource Technology, 50(3), 275-279. https://doi.org/doi:10.1016/0960-8524(94)90102-3

Dai, X., Chen, Y., Zhang, D., \& Yi, J. (2016). High-solid anaerobic co-digestion of sewage sludge and cattle manure: The effects of volatile solid ratio and pH. Scientific Reports, 6(June), 4-13. https://doi.org/10.1038/srep35194

Diaz, R. J., \& Rosenberg, R. (2008). Spreading dead zones and consequences for marine ecosystems. Science, 321(5891), 926-929. https://doi.org/10.1126/science.1156401

Glibert, P. M. (2017). Eutrophication, harmful algae and biodiversity - Challenging paradigms in a world of complex nutrient changes. Marine Pollution Bulletin, 124(2), 591-606. https://doi.org/10.1016/j.marpolbul.2017.04.027

Gold, M., Tomberlin, J. K., Diener, S., Zurbrügg, C., \& Mathys, A. (2018). Decomposition of biowaste macronutrients, microbes, and chemicals in black soldier fly larval treatment: A review. Waste Management, 82, 302-318. https://doi.org/10.1016/j.wasman.2018.10.022

Huang, L., Zhu, W., Ren, H., Chen, H., \& Wang, J. (2012). Global assessment of nitrogen deposition effects on terrestrial plant diversity: a synthesis. Plant Ecology., 213(7), 30-59. https://doi.org/10.1016/S0304-3800(97)01953-4

Isibika, A., Vinnerås, B., Kibazohi, O., Zurbrügg, C., \& Lalander, C. (2019). Pre-treatment of banana peel to improve composting by black soldier fly (Hermetia illucens (L.), Diptera: Stratiomyidae) larvae. Waste Management, 100, 151-160. https://doi.org/10.1016/j.wasman.2019.09.017

Jalaluddin, A., N. Z., \& Syafrina, R. (2018). Pengolahan Sampah Organik Buah-Buahan Menjadi Pupuk Dengan Menggunakan Effektive Mikroorganisme. Jurnal Teknologi Kimia Unimal, 2, 85100. http://ojs.unimal.ac.id/index.php/jtk

Liu, C., Wang, C., \& Yao, H. (2019). Comprehensive Resource Utilization of Waste Using. Animals, 9, 349. doi:10.3390/ani9060349

Mazza, L., Xiao, X., ur Rehman, K., Cai, M., Zhang, D., Fasulo, S., Tomberlin, J. K., Zheng, L., Soomro, A. A., Yu, Z., \& Zhang, J. (2020). Management of chicken manure using black soldier fly (Diptera: Stratiomyidae) larvae assisted by companion bacteria. Waste Management, 102, 312318. https://doi.org/10.1016/j.wasman.2019.10.055

Myers, H. M., Tomberlin, J. K., Lambert, B. D., \& Kattes, D. (2008). Development of black soldier fly (Diptera: Stratiomyidae) larvae fed dairy manure. Environmental Entomology, 37(1), 11-15. https://doi.org/10.1603/0046-225X(2008)37[11:DOBSFD]2.0.CO;2

Newton, G. L., Sheppard, D. C., Watson, D. W., Burtle, G. J., Dove, C. R., Tomberlin, J. K., \& Thelen, E. E. (2005). The black soldier fly, Hermetia illucens, as a manure management/resource recovery tool. The Symposium on the State of the Science of Animal Manure and Waste Management, 5-7.

Oonincx, D. G. A. B., van Huis, A., \& van Loon, J. J. A. (2015). Nutrient utilisation by black soldier flies fed with chicken, pig, or cow manure. Journal of Insects as Food and Feed, 1(2), 131-139. https://doi.org/10.3920/jiff2014.0023

Purnamasari, L., Purnomo, H., \& Setyawan, H. B. (2020). Exploration of local microorganisms from rumen and their potential to make silage from agricultural waste. ASEAN Journal on Science and Technology for Development, 37(3), 109-114. https://doi.org/10.29037/AJSTD.642

Purnamasari, L., Sucipto, I., Muhlison, W., \& Pratiwi, N. (2019). Komposisi Nutrien Larva Black Soldier Fly (Hermetia illucent) Dengan Media Tumbuh, Suhu dan Waktu Pengeringan yang Berbeda. 675680. https://doi.org/10.14334/pros.semnas.tpv-2019-p.675-680

Rehman, K. ur, Cai, M., Xiao, X., Zheng, L., Wang, H., Soomro, A. A., Zhou, Y., Li, W., Yu, Z., \& Zhang, J. (2017). Cellulose decomposition and larval biomass production from the co-digestion of dairy manure and chicken manure by mini-livestock (Hermetia illucens L.). Journal of Environmental Management, 196, 458-465. https://doi.org/10.1016/j.jenvman.2017.03.047

Rezafie, P. A. (2019). Efektivitas Maggot Bsf (Hermetia Illucens) Dan Ulat Kandang (Alphitobius Diaperius) Dalam Pengolahan Limbah Sayur Menjadi Pupuk Organik Dengan Penambahan Limbah Darah Sapi Melalui Proses Vermikomposting. Universitas Muhammadiyah Surakarta.

Sarpong, D., Oduro-Kwarteng, S., Gyasi, S. F., Buamah, R., Donkor, E., Awuah, E., \& Baah, M. K. 
Purnamasari et al.

ANIMPRO: Conference of Applied Animal Science Proceeding Series

(2019). Biodegradation by composting of municipal organic solid waste into organic fertilizer using the black soldier fly (Hermetia illucens) (Diptera: Stratiomyidae) larvae. International Journal of Recycling of Organic Waste in Agriculture, 8(1), 45-54. https://doi.org/10.1007/s40093-019-0268-4

Schmitt, E., \& de Vries, W. (2020). Potential benefits of using Hermetia illucens frass as a soil amendment on food production and for environmental impact reduction. Current Opinion in Green and Sustainable Chemistry, 25, 100335. https://doi.org/10.1016/j.cogsc.2020.03.005

Song, S., Ee, A. W. L., Tan, J. K. N., Cheong, J. C., Chiam, Z., Arora, S., Lam, W. N., \& Tan, H. T. W. (2020). Upcycling food waste using black soldier fly larvae: Effects of further composting on frass quality, fertilising effect and its global warming potential. Journal of Cleaner Production, 288. https://doi.org/https://doi.org/10.1016/j.jclepro.2020.125664

Suciati, R., \& Faruq, H. (2017). EFEKTIFITAS MEDIA PERTUMBUHAN MAGGOTS Hermetia illucens (Lalat Tentara Hitam) SEBAGAI SOLUSI PEMANFAATAN SAMPAH ORGANIK. BIOSFER : Jurnal Biologi Dan Pendidikan Biologi, 2(1), 0-5. https://doi.org/10.23969/biosfer.v2i1.356

Suhartini, S. (2009). Aneka Olahan Ampas Tahu. Trubus Agrisarana.

Surendra, K. C., Tomberlin, J. K., van Huis, A., Cammack, J. A., Heckmann, L. H. L., \& Khanal, S. K. (2020). Rethinking organic wastes bioconversion: Evaluating the potential of the black soldier fly (Hermetia illucens (L.)) (Diptera: Stratiomyidae) (BSF). Waste Management, 117, 58-80. https://doi.org/10.1016/j.wasman.2020.07.050

Tomberlin, J. K., \& Sheppard, D. C. (2002). Factors influencing mating and oviposition of black soldier flies (Diptera: Stratiomyidae) in a colony. Journal Entomology Science, 37(4), 345-352. https://doi.org/https://doi.org/10.18474/0749-8004-37.4.345

Widarti, B. N., Wardhini, W. K., \& Sarwono, E. (2015). Pengaruh Rasio C/N Bahan Baku Pada Pembuatan Kompos Dari Kubis Dan Kulit Pisang. Jurnal Integrasi Proses, 5(2), 75-80. https://doi.org/http://dx.doi.org/10.36055/jip.v5i2.200 